\title{
Civil Service Recruitment: Problems Connected With Federal Character Policy in Nigeria
}

\author{
Emmanuel Jude Abiodun Akinwale, $\mathrm{PhD}$ \\ Department of Business Administration, School of Management and Business Studies, \\ Yaba College of Technology \\ Email: abiodun_akinwale@yahoo.com, Mobile: 08023068147
}

Accepted: May 19, 2014

Doi:10.5296/ jpag.v4i2.5604 URL: http://dx.doi.org/10.5296/ jpag.v4i2.5604

\begin{abstract}
The purpose of this paper is to assess the extent of relevance of the federal character as a national policy in recruitment into the Nigerian federal civil service and probe whether or not the level of application of merit supersedes the application of ecological considerations in recruitment into the service. It utilizes quantitative and qualitative data collection to espouse its theme. The paper finds that there are personnel problems connected with poor application of federal character policy in recruitment into the civil service and this affects the quality of entrants. It recommends strict application of merit standard to attract best workers while implementing federal character policy through proven certification of state of applicants. The paper notes that the Nigerian federal character policy is one that places premium on state representation in governance and bureaucracy and a strategy for national integration. However, there must be predominant application of merit in recruitment.
\end{abstract}

Keywords: Civil Service, Recruitment, Federal Character 


\section{Early antecedents of the Nigerian civil service}

Early antecedents of the Nigerian civil service can be traced to 1861 when the British commenced administration of the Port and Island of Lagos through the creation of scheduled posts. The creation of departments such as Judicial, Police, Prisons, Public Works, Customs, Posts and Telegraph, Marine and Mines featured in 1906. The structure of the Nigerian civil service was created in 1921 by Sir Hugh Clifford who succeeded Lord Lugard as Governor-General of Nigeria. Administrative structure of the service improved through the succeeding years and by October 1, 1960, the federal civil service of Nigeria was established with the high mark of Nigerianization policy. This policy created opportunities for qualified Nigerians to impact the indigenous culture on a hitherto foreign and British culture dominated/oriented civil service (Olusanya, 1975:28). Recruitment policy implementation in the Nigerian federal civil service after independence also featured Southernization and Northernization policy which meant that the southern and northern civil services preferred applicants whose origin were from the southern and northern parts of the country. This ethnic trend was partly corrected with the application of the federal character policy empowered constitutionally to control the exclusion of a few states or a few ethnic groups in the composition of government and its agencies. This policy was given recognition with the 1979 Constitutional provisions and plan for national integration with the expectations for nation building bearing in mind equal applications of merit and ecological factors in recruitment.

\subsection{Nigerian Civil Service Recruitment: The Federal Character Policy}

The Federal Character Commission in Nigeria was established by section 153 (1) of the 1999 Constitution with antecedents traced to 1996 through Decree No 34 of 1996 (the Enabling Act). This Act emanated from recommendations of the 1994/95 constitutional conference. The Commission was established to give effect to section 14 (3) and (4) of the Constitution which provides as follows:

The composition of the government of the federation or any of its agencies and the conduct of its affairs shall be carried out in a manner as to reflect the federal character of Nigeria and the need to promote national unity and also common national loyalty thereby ensuring that there shall not be predominance of persons from a few states or from a few ethnic or other sectional groups in that government or any of its agencies.

The Federal Character Commission is a federal executive body established to implement and enforce the federal character principle of fairness and equity in the distribution of public posts; socio-economic amenities and infrastructural facilities among the federating units of the Federal Republic of Nigeria. The Commission is also empowered to operate in a democratic setting (1999 Constitution).Its antecedents can be traced to the colonial period when recruitment into the Nigerian Armed Forces was processed through quota system to ensure that no one particular section of the country dominated the military. The success of the implementation of the federal character policy in the military culminated in the call for its application in the Nigerian federal civil service. Regrettably, while the federal character policy was preferred in some sections of Nigeria, some other sections rejected the implementation of the policy. The (Act) establishing the Commission with specific reference 
to part iv of federal character principles and selection process for recruitment into the Federal Public Service and as stated in the Federal Character Commission Handbook (1996) are as follows:

- The Federal Character Commission is mandated by Section 4 (1) (g) of its Enabling Statute to ensure, inter alia, that all Ministries and Extra-Ministerial Departments, Parastatals and other Government Agencies have a clear criteria including conditions to be fulfilled and comprehensive guidelines on the procedure for determining eligibility as well as the procedure for employment into the Public Service.

- In view of the above, and in order to ensure smooth implementation of the Federal Character Policy on employment into the Federal Public Service without in any way compromising merit, the Commission requires all employers of labour in the federal civil service to comply with extant regulations of the Commission on employment.

- The purpose of the guidelines is to streamline the selection process, such that the best and most competent persons from each state of the Federation are employed thereby ensuring that the principle of merit is upheld. Accordingly, the following process shall be followed in filling all existing vacancies, particularly at the entry level in all Public Service Establishments, nationwide:

- Vacancies should be advertised in at least two newspapers circulating nationally, giving prospective candidates, a minimum of six weeks to apply. This is to enable wide dissemination of the information so as to attract the best materials from all parts of the country.

- Where vacancies are advertised on the internet, this should not, for now, preclude similar advert in two newspapers aforesaid and prospective candidates should still be given six weeks to apply. This requirement is necessary given the low level of internet access by a vast majority of the populace.

- Employers of labour should ensure that they have comprehensive job description for each vacant position as well as comprehensive academic and cognate experience required for filling such vacancies.

- Only candidates who have met the basic minimum requirements for each position should be shortlisted for interview or other selection process. Under no condition should an unqualified candidate be shortlisted purportedly on the basis of federal character. However, once a candidate has met the basic minimum requirements, he should not be penalized in favour of another or other candidates who might possess higher qualifications but should qualify to compete for positions reserved for his State. 
- Qualified and competent candidates are to be shortlisted for interview or other selection mode on State basis, and drawn as much as possible, in equal number from each State of the Federation, indicating also, their Local Government Area. A quarter of the number of candidates from each State shall be drawn from the Federal Capital Territory. The best and most competent candidates from each State of the Federation and the Federal Capital Territory shall be shortlisted to compete for positions reserved for their respective States.

- Where an aptitude test or any other type of written or oral test is required as part of the selection process, the compilation of results should be on State by State basis, to enable the best from each State and the Federal Capital Territory be employed.

- The list of shortlisted candidates as well as the final list of candidates offered employment shall be forwarded to the Commission.

- To ensure compliance with the above selection process, the Commission requests for representation as observer at all recruitment interview for prospective employees.

- Accordingly, it shall be notified of and invited to such recruitment exercise at least two weeks in advance. It shall be the responsibility of all Permanent Secretaries/Chief Executives of all Ministries/Extra-Ministerial Departments, Parastatals, Agencies and other Federal Government Establishments to ensure compliance with the above process.

\subsection{Existing Opinions on the Federal Character Policy}

This paper notes opinion of writers on problems connected with the federal character in recruitment into the civil service of Nigeria and identifies aspects that have not been explored to entrench merit principle in implementation of recruitment policies. Such aspects include firm resolve to prevent mediocrity by implementers of the federal character policy. It also notes the three basic requirements for recruitment into the Nigerian federal civil service which are good qualifications, availability of vacancy and the federal character requirement. The federal character is a significant aspect of recruitment policy in the civil service designed to ensure states representation in national appointments. Decree No 43 of 1988 on reorganization of the Nigerian civil service, restricted this factor to entry points in mid-senior management levels of the civil service and the responsibility was assigned to the Federal Civil Service Commission charged with the duty of appointments and discipline of officers appointed into the Nigerian civil service.3 Wahab (2009:8) notes that the federal character policy is valuable in giving representation to all sections of Nigeria. However, it should not be a permanent policy as it negates standard principle of merit. Wahab (2009:8) is also of the view that introduction of the federal character policy in recruitment is likely to have a measure of attraction for poor quality workforce as a result of seeking political balance in 
recruitment.

Nnoli (1987) explains that the federal character policy is not synonymous with mediocrity, neither does it entail replacing serving officers from particular sections of the country with those from sections not fully represented in the civil service. However, implementation of the federal character policy is affected by inadequate recognition of the merit principle. This results in recruitment of federal civil servants with low qualifications and experience. Some federal civil servants recruited through federal character policy rather than by merit have demonstrated inadequate knowledge and incompetence on the job at various level of the service. The poor implementation of the federal character policy had led to recruitment of some bureaucrats from the northern parts of the country into the federal civil service without the prerequisite qualifications, experience and skills to prominent positions as Directors and Permanent Secretaries. This was discouraging and disheartening to the bureaucrats from the southern part that advances to their respective positions through competitive examinations and rigorous interviews. This can be ascribed as one of the many factors that disorganized and confused the civil service structure and ethics in Nigeria.

Gboyega (1989:178-179) appraises the implementation of the federal character principle as characterized by arbitrary appointments and removals especially during the lengthy years of military rule in Nigeria. Southern bureaucrats saw it as constraint to their proper placement and this de-motivated them as their sense of belongingness was affected. Suberu (2001:111) has similar negative observations on the federal character principle and analyzes the varying degrees of assessment of the principle. He was of the view that Northerners preferred the policy as a tool for representative bureaucracy while southerners saw it as a discriminatory tool for recruitment. A similar view is expressed by Okpu (1989) that the federal character policy tended to favour northerners while southerners were negatively affected in terms of its implementation. Furthermore, Oyovbaire (1983:25) in his assessment of the federal character policy in recruitment into the federal civil service sees the policy as affecting efficiency in recruitment and paving the way for mediocrity in positions of authority. An analysis of the federal character policy in theory was to bring about national unity. However, this resulted in negative implications of implementation of equal representation of states in recruitment into the civil service. Regrettably, the defunct Nigerian Constitution of 1989 (Section 150) entrenched the application of the federal character policy as such that it extended to appointments to governing boards and institutions. The federal character policy is relevant in a diverse state like Nigeria but meritocratic considerations must not be under-estimated. The policy has been applied in terms of sharing of bureaucratic appointments and has culminated in a disjointed Nigerian bureaucracy. Similarly, Adamolekun et al (1991:80) posits that the federal character policy tolerates the rights of groups in a society but results in a group cohesion and elite manipulation. This view is shared by Brass (1991) who sees the federal character principle as negative to showcase individual competence. Thus, to solve the problem of implementation of the federal character policy in recruitment, equal basis of considerations have to be introduced so that no one group is placed at a disadvantage. In all these appraisals, it is clear that meritocratic considerations give positive direction to the implementation of recruitment policies in the federal civil service of Nigeria if followed to 
the letter, rather than self- interest considerations of federal character.

To solve the problems of implementation of the federal character policy in Nigeria, it is necessary to borrow from the strategies applied by other countries with similar experience. This is because the improvement of the internal efficiency of the Nigerian federal civil service involves continuous reforms and these reforms serve as strategies for improving the internal efficiency of the federal civil service. Before we can get to the utopia in terms of the Nigerian federal civil service we intend to reposition, we need to revamp the human, material, financial resources and skills of bureaucrats. This will create an effective human capital development of the federal civil service. Kiragu (1998:5) examines the recruitment process in South Africa and discloses the application of merit principles and practices in public service appointments with the objective of restoring the competence, motivation, integrity and accountability of civil servants. In this country, there are targeted public instruments to create more employment opportunities. Kiragu (1998:5) also notes that Tanzania has improved remuneration of civil servants with the goal of enabling the government to recruit and retain competent staff in competition with other sectors. In his analysis of the civil service of African countries, Kiragu (1998:5) is of the view that good governance is usually synonymous with an efficient and effective civil service. He adds that such a service promotes through the political leadership, an enabling environment for the social, political and economic development of the country. The problems that characterize the poor state of the civil service systems in African region include: excessive high levels of government employment as well as non-transparent and patronizing basis for appointments.

A national newspaper editorial comment is of the view that:

There is a convincing argument that though the federal character principle is backed by the constitution, it has become outdated. Every part of the country now has competent people that can compete for important public positions in the land. It is therefore puzzling that for just immediate political gains, certain individuals and groups are ready to abjure the provisions of the nation's constitution in favour of what appears to be a selfish agenda. (Sunday Punch - May, 2010)

From the foregoing, it can be observed that the federal character policy should recognize the strength of the merit principle. However, the aspect of politicization of recruitment policies makes the merit principle vulnerable. In Nigeria, the merit principle in recruitment is affected by the politicization of the civil service. Politicians tend to give their supporters at polls the opportunity of employment in the civil service and this affects in large measure, the application of the merit principle. Furthermore, the federal character policy is valuable to pave the way for national unity and equal contributions of Nigerians to the federal cause but unnecessary for implementation of recruitment policy. Policies for unity such as the National Youth Service Corps (NYSC), and others such as Mass Mobilization for Social and Economic Recovery (MAMSER), Better Life for Rural Women and National Poverty Reduction Programme (NAPEP) that encourage national unity had been applied sufficiently to unite Nigeria as a nation. Consequently, application of merit in implementation of federal character in recruitment at this stage of Nigeria's advancement would offer positive 
implications for the future of the federal civil service and address the problems of implementation of recruitment policies in Nigeria.

\section{Application of Theories Relevant to Bureaucratic Institutions}

Theories provide valuable basis for organizing facts and observations. This paper is concerned primarily with problems connected with the implementation of the federal character as a recruitment policy in the Nigerian federal civil service. It applies theories relevant to bureaucratic institutions in comparative perspectives because of their relevance to comparative public sector recruitment. This is relevant in the light of diversities in the Nigerian society that led to the application of charismatic and traditional forms of authority in recruitment of personnel into the federal civil service. In line with classical Weberian view of legal-rational authority (Weber,1950), this paper deduced that the federal civil service of Nigeria must implement recruitment policy relating to federal character in line with federal character guidelines but with strict application of merit principle (Akindele, 1987:22). There is also an appreciable note in the distinction between civil service recruitment in developed and developing countries. Modern countries place premium on high bureaucratization and reliance on constitutional processes. However, bureaucracies of poor countries especially those of Africa, suffer constraints of right procedure for implementation of recruitment policies. This supports the view that the federal civil service of Nigeria is affected by improper application of the federal character policy and makes it difficult to follow acceptable standards of recruitment as applied in wealthy bureaucracies (Easman, 1980:426).

This paper utilizes both the systems theory and the policy process model because of the interdependent functions of bureaucracy in formulation and implementation of policies. While the systems theory focuses on the interdependent role of organizations and their environment, the policy process model becomes more applicable as it prescribes the guidelines on policy formulation and implementation in organizations. The policy process model focuses on political processes and involves stakeholders. It also examines the social, economic, political and cultural factors influencing policy formulation and implementation (Anderson, 1978). The methodology of the policy process is significant as it defines problems and evaluates the criteria for solving problem. It also proffers alternatives to problem solving and recommends the applicable policy agenda. Policy models exist to appraise public policy and these include the institutional model (legitimacy of policy), rational model (cost effectiveness of policy), incremental model (periodic review of policies), group model (harmonization of conflicting interest by political systems), and the elite model (reflection of interest of the elite rather than the public) - (Anderson, 1978). The relevance of the systems and policy process model to this paper is the ecological factor that impacts on application of merit system in recruitment into the federal civil service and the most significant ecological factor is the federal character policy. Application of the federal character policy must place premium on merit for the success of the policy rather than application on discretional basis. The policy process model and the systems theory are adopted based on focus on application of policy guidelines and recognition of functional relevance of policies. 
The paper's further application of the policy process model is relevant due to model's prescription for successful implementation through proper evaluation of policies. A catalogue of variable affects recruitment policy implementation in the Nigerian federal civil service. Among these variable are the aspect of the federal character. The federal character policy prescribes that where quota is applied, selected applicants for a vacant position must be selected with the basis of merit. However, implementation of this has been a problematic issue in the recruitment procedure of the federal civil service. This result in implementation gap which the policy process model addresses through the prescription of evaluation of policies formulated. The success of the Nigerian federal civil service is highly dependent on its determination to ensure effective recruitment policy implementation. This can be achieved through practice of strict advisory roles by bureaucrats. Furthermore, government must ensure that policies formulated meet the needs and aspirations of the citizens. The success of implementation is also tied to the consideration of realities of policies formulated for the diverse people of the Nigerian society which makes imperative the application of the federal character policy. The paper's adoption of the policy process model to assist recruitment implementation rests on the need to ensure evaluation of the functional role of the Nigerian federal civil service which include among others, utility functions, (welfare services), domestic functions, custodian of rules and regulations and ensuring the continuity of government.

The continuance of government requires reassessment of formulation and implementation of recruitment policies as well as examination in relation to their consequences. This aspect of evaluation prescribed by the policy process model determines the extent of success of policies formulated and also determines how they can be improved or redesigned. The policy process model is a complex process as it requires strict application of processes of formulation and implementation of policies. Thus, the study adopts the policy process model for the success of recruitment policy implementation role of the Nigerian bureaucratic machine (federal civil service). The role of bureaucrats as implementers requires faithful compliance with policies formulated to achieve the success of implementation.

\subsection{Appraisal of Application of the Federal Character Policy in Nigeria}

The Federal Character Commission is relevant in a diverse state like Nigeria. The policy sustains the representation of ethnic majorities and ethnic minorities in the country. Mustapha (2006) notes the three major ethnic groups in Nigeria. These are the Hausa-Fulani of the North, the Yoruba of the Southwest and the Igbos of the Southeast. The pace towards nationalism brought about the approaches of recruitment into the Nigerian federal civil service. The educational imbalance between the northern and southern states had impact on recruitment into the federal civil service. To maintain equilibrium, the federal character policy was introduced to provide for the participation of indigenes of respective states in the federation in bureaucracies and institutions and for securing national integration. The federal character policy is also relevant to recruitment in a country like Nigeria with various ethnic diversities. Meritocratic considerations alone would have been controversial in a country where ecological factors are pronounced. The merit system however includes the attempt to ensure that educational and bureaucratic facilities are shared among respective states of the 
federation. It is imperative that federal character as a principle of equal participation should recognize qualification and merit. The policy is also aimed at bridging the gap of educational imbalance that the Northern part of Nigeria has suffered for a long period of educational development since independence (Tamuno, 1984:398). Despite the educational imbalance with southern counterparts, northerners preferred to have expatriates rather than southerners when northerners with required qualification for employment were not available. The north distrusted the use of southerners in their civil service. Federal character is expected to recognize the rights of heterogeneous societies and identify the best in terms of merit for recruitment when vacancies occur. The federal character policy is relevant in recruitment into the federal civil service. However, its application must recognize the inclusion of the merit system which the federal character policy and selection process for recruitment into the federal civil service provides in the extant rules.

\subsection{Problems connected with the application of the federal character policy}

The federal character commission calls for advertisement of vacancies in at least two national dailies for effective application of the policy. However, some good quality graduates prefer to seek for employment along the lines of nearness to their geographical zones. Significantly, most tertiary institutions, particularly universities opt for temporary recruitment that are later regularized by their governing councils due to urgent need to fill vacancies arising from transfers, secondments, study leave, sabbatical, study fellowships/ exchanges, leave of absence, resignations, deaths, dismissals and allied personnel exit factors. These urgent recruitment factors are challenges to observation of the federal character policy. There are also instances when the predominance of entrants from particular state results in stoppage of recruitment of applicants from such states to justify the geographical spread occasioned by application of the federal character principle. Regrettably, some applicants do not provide authentic information of their state of origin to access the advantage of state catchment in recruitment into the Nigerian federal civil service. Others decide to stagger reference of their state of origin with those of their spouses as the state catchment favours in recruitment. These problems affect enforcement of sanctions on defaulters of the federal character policy and weaken compliance with the policy.

\section{Methodology}

This paper employs both the quantitative and qualitative research methods to appraise problems connected with the application of the federal character as a recruitment policy in Nigerian federal civil service. It also applies a descriptive survey method to explain the main theme of the paper and describe factors responsible for constraints in the application of the federal character policy.

\section{Field survey and questionnaire administration}

\section{- Study Population}

The study population comprises ministries in the federal civil service of Nigeria. These include: 


\section{Macrothink}

- Federal Ministry of Establishments and Pensions, Abuja.

- Office of the Head of Civil Service, Abuja.

- Federal Ministry of Information and Communication, Abuja.

- Federal Ministry of Finance, Abuja.

- Federal Ministry of Commerce and Industry, Abuja.

- Federal Ministry of Education, Abuja

- Federal Ministry of Heath Abuja

It also included the leadership of the federal civil service, through the office of the Head of federal civil service. The objective of the selected locations was based on representativeness of the workforce in the selected federal ministries as the workforce includes civil servants from all the thirty-six states of Nigeria. The staff strength of each of the seven ministries comprised approximately five thousand $(5,000)$ workers. The workforce of approximately thirty-five thousand $(35,000)$ was utilized out of which seven hundred were randomly selected.

- Questionnaire administration

Figure 1: Opinions that recruitment and placement of good quality civil/public

Servants are affected by poor implementation of federal character policy.

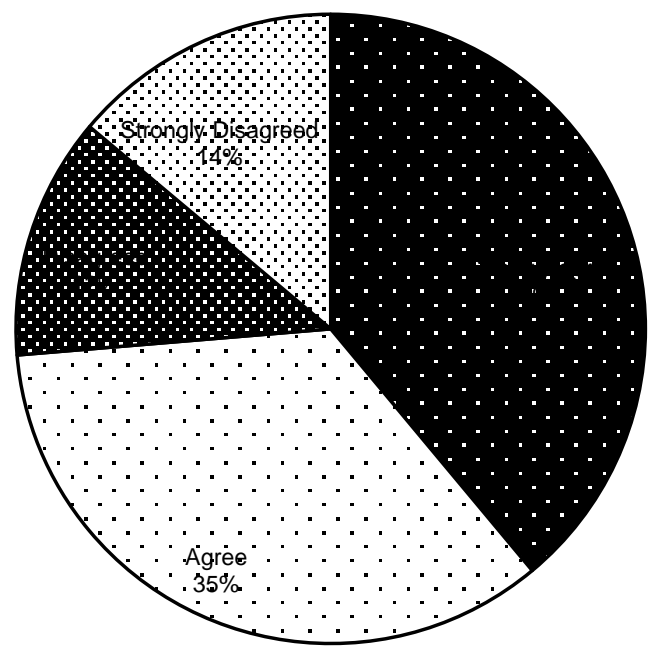

Source: Data Administered By the Author, 2011 


\section{Macrothink}

Majority of the respondents in figure 1 amounting to 403 (73.68\%) agree that recruitment and placement of good quality civil/public servants is affected by poor implementation of federal character policy while 144 (26.32\%) disagreed.

\subsection{Sample Size}

A sample size of seven hundred (700) was utilized from seven selected institutions that comprised approximately thirty-five thousand $(35,000)$ members of staff. This sample size averages 100 respondents per ministry and is based on limitations of fieldwork.

\subsection{Sampling Method}

To obtain objectivity among the three levels of employees in management which includes low, middle and top level employees, the stratified random sampling was employed. The questionnaires were distributed equally as follows; Federal Ministry of Establishments and Pensions (100); Office of Head of Civil Service Abuja (100); Federal Ministry of Information and Communication, Abuja (100); Federal Ministry of Finance, Abuja (100), Federal Ministry of Commerce and Industry, Abuja (100), Federal Ministry of Education, Abuja (100) and Federal Ministry of Health, Abuja (100). The sample comprises top level employees (Grade Level 15 to 17), middle level employees (Grade Level 7 to 14) and junior level employees (Grade level 01 to 06). The number of sample employed was to achieve an equal representation of views among the relevant management strata of federal civil servants that were administered with questionnaires. 
Table 1: Questionnaire Analysis

\begin{tabular}{|l|c|c|c|c|c|}
\hline \multicolumn{1}{|c|}{ Ministries } & $\begin{array}{c}\text { No. of } \\
\text { questionnaires } \\
\text { distributed }\end{array}$ & $\begin{array}{c}\text { No. of } \\
\text { questio } \\
\text { nnaires } \\
\text { returne } \\
\text { d }\end{array}$ & $\begin{array}{c}\text { No. of } \\
\text { questionnai } \\
\text { res } \\
\text { unreturned }\end{array}$ & $\begin{array}{c}\text { Percenta } \\
\text { ge (\%) } \\
\text { returned }\end{array}$ & $\begin{array}{c}\text { Percenta } \\
\text { ge (\%) } \\
\text { Unretur } \\
\text { ned }\end{array}$ \\
\hline $\begin{array}{l}\text { Federal Ministry of } \\
\text { Establishments and Pensions, } \\
\text { Abuja }\end{array}$ & 100 & 79 & 17 & 79 & 17 \\
\hline $\begin{array}{l}\text { Office of Head of Civil Service } \\
\text { Abuja }\end{array}$ & 100 & 76 & 24 & 76 & 24 \\
\hline $\begin{array}{l}\text { Federal Ministry of } \\
\text { Information and } \\
\text { Communication, Abuja }\end{array}$ & 100 & 89 & 16 & 89 & 16 \\
\hline $\begin{array}{l}\text { Federal Ministry of Finance, } \\
\text { Abuja }\end{array}$ & 100 & 69 & 28 & 69 & 28 \\
\hline $\begin{array}{l}\text { Federal Ministry of Commerce } \\
\text { and Industry, Abuja }\end{array}$ & 100 & 68 & 21 & 68 & 21 \\
\hline $\begin{array}{l}\text { Federal Ministry of Education, } \\
\text { Abuja }\end{array}$ & 100 & 90 & 15 & 90 & 15 \\
\hline $\begin{array}{l}\text { Federal Ministry of Health, } \\
\text { Abuja }\end{array}$ & 100 & 76 & 32 & 76 & 32 \\
\hline Total & $\mathbf{7 0 0}$ & $\mathbf{5 4 7}$ & $\mathbf{1 5 3}$ & $\mathbf{7 8 . 1 4}$ & $\mathbf{2 1 . 8 6}$ \\
\hline
\end{tabular}

\section{Source: Data Administered By the Author, 2011}

\subsection{Findings}

The study finds that Nigeria as a heterogeneous country applies the federal character policy in recruitment. However, the civil service rules as it concerns recruitment emphasizes good qualifications and merit. The study also finds that both the formulators and the implementers of the federal character policy in Nigeria do not request applicants to provide evidence of their state of origin in the application of federal character policy for merit selection on state basis in recruitment practice.

\subsection{Conclusions}

The federal character policy is a constraint to the implementation of recruitment policies in Nigeria. This policy may be justified from the angle of representativeness of all the thirty (36) states in Nigeria in recruitment practice. Adoption of meritocratic approach in recruitment without reference to federal character policy will not affect the sustenance of national integration as other institutional policies for national integration exist. However, the federal character policy unnecessarily over-emphasizes sharing of vacancies on state basis in recruitment to poor application of merit. The federal civil service of Nigeria will attain giant 
strides in recruitment with predominant application of merit over federal character, quota, representativenesss and vacancy needs in the implementation of recruitment policies in Nigeria.

\section{Recommendations}

The inadequate predominant integration of merit in the implementation of the federal character policy is ascribed to the failure of bureaucrats to strictly adhere to the inter-dependent application of the principle of merit and federal character. The study finds that implementation the federal character policy affects strict application of merit whereas, the framers of the federal character policy did not intend to sacrifice merit in its implementation but to ensure harmonization of merit and ecological approaches in civil service recruitment. A major contribution of this paper is its call for predominant application of merit in Nigerian civil service recruitment while observing the federal character policy as the bureaucracies of third world countries including Nigeria are the pillars in which good governance rests. The policy should be applied only when there are ties in scores of applicants worthy of selection after interview. Merit is compromised when lower scores of applicants are favoured due to compliance with federal character policy. Also, the prescription of the federal character policy that vacancies be advertised in at least two national dailies does not necessarily attract responses from applicants across the thirty six states of the federation as applicants prefer nearness to their state geographical zones due to problems connected with ethnic crisis in Nigeria.

The federal character policy is applied in Nigerian civil service recruitment with poor database on state population. A significant number of civil servants in Nigeria provide sworn declaration of ages rather than registered birth certificates to prove their ages as authentic. This implies that significant parts of the population were not registered at birth. The puzzle therefore is the challenge of unreliable database on state of origin for effective application of the federal character policy. This paper recommends that to prevent falsification of information on state of origin, the National Population Commission must avail institutions with a comprehensive database and provide job seekers with certificates of state of origin for verification purposes if the federal character requirement is to be continued as a recruitment policy into the Nigerian civil service.

\section{References}

Adamolekun, L. and Kincaid, J. (1991). The Federal Solution: Assessment and Prognosis for Nigeria and Africa. Publius: The Journal of Federalism, PP. 173-189.

Akindele, S.T. (1986). Synthesizing Bureaucracy and Democracy: A Revisit. Journal of Administration (1\&2).

Anderson, J.A. (1978). Public Policy Making. New York: Harcourt.

Brass, P. R. (1991). Ethnicity and Nationalism: Theory and Comparison. New Delhi: Sage. 
Constitution of the Federal Republic of Nigeria. (1999). Lagos: Federal Government Press.

Easman, M.J. (1980). Development Assistance in Public Administration: Requiem or Renewal. Public Administration Review 40:426-31.

Federal Character Commission Handbook (1996). Abuja. Presidency.

Gboyega, A. (1989). The Public Service and Federal Character. In P.P. Ekeh and E.E. Osaghae (eds). Federal Character and Federalism in Nigeria. Ibadan: Heinemann.

Kiragu, K. (1998). Civil Service Reforms: in Southern and Eastern Africa: Lessons of Experience. Report on Proceedings of a Consultative Workshop held at Arusha. Tanzania. March 4-6, 1998, P. 5.

Mustapha, A.R. (2006). Ethnic Structure, Inequality and Governance of the Public Sector in Nigeria, Democracy, Governance and Human Rights Programme. Paper Number 24, United Nations Research Institute for Social Development.

Nnoli, O. (1990). Ethnic Politics In Nigeria. Enugu: Fourth Dimension Publishers

Olusanya, G.O. (1975). The Evolution of the Nigeria Civil Service 1861-1960, The Problems of Nigerianization. Humanities Monograph Series. Lagos: University of Lagos.

Okpu, U. (1989). Ethnic Minorities and Federal Character. In Ekeh, P.P. and Osaghae, E.E. (eds), Federal Character and Federalism in Nigeria. Ibadan: Heinemann.

Oyovbaire, S.E. (1983). Structural Change and Political Processes in Nigeria. African Affairs. No. 326, PP. 3-28.

Public Service Rules (2000). Abuja: Federal Government Press.

Suberu, R. (2001). Federalism and Ethnic Conflict in Nigeria. Washington DC:UnitedStates Institute of Peace Press.

Sunday Punch Editorial. Punch Newspapers. May, 2010.

Tamuno, G.O. (1984). British Colonial Administration in Nigeria in the Twentieth Century. In Obaro Ikime (ed). Groundwork of Nigerian History. Ibadan: Heinemann Educational Books (Nig.) Ltd.

The Nigerian Constitution: A Compendium 1963, 1979 and 1999. Law Lords Publications. Olajide Olakanmi. Ekiti State, Efon Alaye "Panaf".

Wahhab, M.A. (2009). Civil Service Recruitment Policy in Bangladesh: A Critical Analysis. Paper Submitted for NAPSIMAG International Conference2009,Malaysia,Executive Development Centre Development Centre, University Utara, Malaysia, Kedah, $11-13$ December, 2009.

Weber, M. (1950). The Protestant Ethic and the Spirit of Capitalism. Hammersmith. London. U.K: Harper-Collins Academy. 